Article

\title{
Legal Regulation of Campaign Deliberation: Lessons from Brexit
}

\author{
James Organ \\ School of Law and Social Justice, University of Liverpool, L69 3BX, UK; E-Mail: james.organ@liverpool.ac.uk
}

Submitted: 20 December 2018 | Accepted: 14 February 2019 | Published: 27 June 2019

\begin{abstract}
There has been significant attention paid to explaining and understanding the impact of the UK's vote to leave the EU on UK politics and its constitution. There has also been criticism of the political campaigning, from both the "leave" and "remain" sides, and of people's understanding of what they were voting for. There has been limited discussion, though, of how to improve the quality of campaign deliberation, which is fundamental to the legitimacy of both representative and direct democratic processes. Using the UK's vote on EU membership as a case study, this article examines the importance of the law to regulate and improve deliberation prior to direct public votes on specific policy issues. It also considers options for changes to the law and for its implementation, using the current provisions about false statements in electoral law as a starting point. The article argues that the quality of deliberation during UK referendum campaigns needs to improve and that legal regulation should be developed. There are, however, significant challenges in drafting legislation that appropriately defines and limits the use of misleading statements, and at the same time avoids excessive restriction of free speech, or an excessively political role for regulatory bodies and the courts. Given the nature of political campaigning and the challenges in reducing the use of misleading statements by political actors through legal regulation, increased deliberative opportunities for citizens are proposed as a complementary, perhaps more effective means to positively enhance deliberation in political campaigns. Whatever approach is taken, direct democracy needs to be combined effectively with representative democracy, based on a common underlying principle of the importance of deliberation, and not treated as a separate part of a state's democracy.
\end{abstract}

\section{Keywords}

Brexit; deliberation; democracy; electoral law; false statements; plebiscite; referendum

\section{Issue}

This article is part of the issue "The Politics, Promise and Peril of Direct Democracy", edited by Todd Donovan (Western Washington University, USA).

(C) 2019 by the author; licensee Cogitatio (Lisbon, Portugal). This article is licensed under a Creative Commons Attribution 4.0 International License (CC BY).

\section{Introduction}

The vote on the UK's EU membership was one of the most important decisions ever put to the UK electorate. In a plebiscite ${ }^{1}$ people were asked a single, seemingly straightforward question-should the UK remain a member of the EU or leave the EU? There were active, highprofile campaigns involving political and non-political actors, a high turnout by UK standards and a clear, if narrow, vote to end the UK's EU membership. The response from the electorate, in theory, provided a clear, democratic mandate on this crucial policy issue; the sort of legitimate democratic mandate delivered to a political party every few years at a general election. Despite the similarities to previous votes, the UK's EU membership plebiscite received heavy criticism, particularly with regard to the quality of information, level of debate and how well-informed voters were (Lamond \& Reid, 2017). The campaigning of both the "leave" and "remain" sides was criticised for its inaccuracy, tone and weakness in supporting effective public deliberation, and over half of voters thought that the campaigning was not fair and balanced (The Electoral Commission, 2016, p. 7). Despite the legitimacy of the result being undermined by these

\footnotetext{
1 The UK's vote on EU membership was a government-initiated public vote and therefore a plebiscite. The term 'plebiscite' is used in this article when referring specifically to the UK's EU membership vote and 'referendums' as a generic term when talking about plebiscites and referendums in general.
} 
problems, there has been limited discussion of how to improve the quality of deliberation and reduce the manipulation of voters through misleading and inaccurate information in political campaigning (The Constitution Unit, 2018).

There was a clear problem with political actors making inaccurate and misleading claims during the campaigning prior to the UK's plebiscite on EU membership. Perhaps, the best-known example from the remain side was the prediction that each household would be $£ 4,300$ worse off (Her Majesty's Treasury, 2016). This precise government prediction based on just one possible future EU-UK relationship was described as "at best a red herring...an unhelpful summary of the underlying research" (Full Fact, 2016). Another less memorable, but even more unsound claim was the "demonstrably false" statement by Alan Johnson that: "Two thirds of British jobs in manufacturing are dependent on demand from Europe" (Stone, 2017). On the "leave" side, we had the controversial prediction that a million Turkish migrants would come to the UK, if the UK stayed in the EU, and the false claim that the UK would save $£ 350$ million per week, if it left the EU (Vote Leave, 2016). Should all of these claims be an illegal practice or are they an accepted part of free political discourse? The final two claims, which citizens were most likely to remember after the plebiscite was held, are discussed in more detail below in relation to this question. Through the lens of the UK's 2016 plebiscite on EU membership, therefore, this article looks at how electoral law and deliberative democratic instruments might be used to improve deliberation prior to any future referendums (Tierney, 2013). With direct democracy apparently here to stay as part of the constitution in the UK-perhaps another vote on the UK's EU relationship or on Scottish independence-and also in other states across Europe (Qvortrup, 2018; Mendez, Mendez, \& Triga, 2014), such changes are urgently needed.

Access to impartial, accurate information from trusted sources about the issues related to a decision put to citizens at a referendum or an election is an essential aspect of democratic deliberation. Having received this information, there needs to be well-informed, reasoned debate and deliberation about the value implications of the options put to them. As Tierney (2015) said:

If a referendum is to overcome the elite control and deliberation deficit criticisms it must be shown to offer a meaningful space for an exercise in collective public reason by citizens who understand an issue, engage with it, and are able to make an informed decision relatively free from elite-led influences and pressures. (p. 637)

Without this, key democratic principles, such as popular sovereignty and equality, and criteria for democratic legitimacy, such as effective participation and enlightened understanding, Dahl (1989) are undermined. Referendums can meet the criteria for democratic legitimacy but they need careful process design and drafting of the law. Tierney (2012) This article focuses on increasing the quality of deliberation during referendum campaigns, which is one method to limit the opportunity for elite political interests to manipulate a referendum vote. "Elite control" is a particular concern for plebiscites because, by definition, these votes are controlled by the executive (Mendelsohn \& Parkin, 2001). To analyse deliberation within the wider debate about the legitimacy of referendums, this article proceeds as follows: First it examines the UK law on false statements and the scope of its application. Secondly, it discusses two misleading statements from the Vote Leave group in light of electoral law and challenges in framing an extension to the law. Thirdly, there is discussion of how an extended electoral law might be implemented and enforced in practice. Given the difficulties in developing legal controls of deliberation in the referendum process, and that this focus on legislation might not be sufficient (Henderson \& Tierney, 2018), the article's final section proposes deliberative methodologies as a complementary, perhaps more effective means to positively enhance deliberation in political campaigns from a citizen rather than political actor perspective.

The overall argument is that the law needs to change to act as a stronger deterrent for false statements during political campaigning to increase the quality of deliberation prior to a public vote, and hence the legitimacy of the result. There are challenges, though, in drafting legislation to regulate deliberation in the political environment of an electoral or referendum campaign, particularly if the legal scope were to be increased to include political statements of the sort that were problematic during the UK's EU membership plebiscite. A careful balance needs to be struck between political freedom and robust campaigning, and the desire to increase accuracy of information and deliberation during those campaigns (Rowbottom, 2012). An extension of electoral law also runs the risk of bringing the courts, and other regulatory bodies, inappropriately in to the political arena. Given the limited degree to which the law can control political actors' attempted manipulation of the public discourse, increased use of deliberative instruments, such as citizens' assemblies, during campaigns are proposed as a further means to enhance deliberation and reduce the effect of misleading statements. Whatever approach is taken to improving the quality of political discourse and to having well-informed citizens, referendums need to be combined effectively with representative democracy, based on a common underlying principle of the importance of deliberation to democratic legitimacy, and not regulated or developed as a separate part of a polity's democracy.

\section{Electoral Law Relating to False Statements}

The focus in UK electoral law is on "vote rather than voice" (LeDuc, 2015, p. 139), on the fairness of the vote itself rather than on prior deliberation. The UK has a high 
level of regulation for voting processes (Suiter \& Reidy, 2015) but the only legal provision in UK law that directly influences deliberation is the obligation not to make false statements during an election campaign. This has been an offence since the 19th century, and is now Section 106 of the Representation of the People Act 1983 (RPA). The Act states:

S106 False statements as to candidates.

(1) A person who, or any director of any body or association corporate which-

(a) before or during an election,

(b) for the purpose of affecting the return of any candidate at the election,

makes or publishes any false statement of fact in relation to the candidate's personal character or conduct shall be guilty of an illegal practice, unless he can show that he had reasonable grounds for believing, and did believe, that statement to be true. (Parliament of the United Kingdom, 1983)

If the petition to the election court is upheld and the respondent is found guilty of an illegal practice according to S106 RPA 1983, then their election shall be void (Parliament of the United Kingdom, 1983, S159 (1)). The Court can also restrain a person from repeating false statements by granting an interim injunction. (Parliament of the United Kingdom, 1983, S106(3)). The law is not applicable to referendums and is limited in scope in relation to the election of representatives. This is highlighted in two recent cases: the Phil Woolas case in 2010 and the Alistair Carmichael case in 2015.

In 2010, during his campaign to be MP for the Oldham and Saddleworth constituency, Mr Phil Woolas claimed in a pamphlet and other media that his nearest rival, Mr Robert Watktins, had attempted to woo the vote of Muslims who advocated violence, had refused to condemn extremists who advocated violence against $\mathrm{Mr}$ Woolas, and had reneged on his promise to live in the constituency. Mr Watkins brought a petition to the electoral court that these three claims were false statements that contravened S106 RPA (Watkins v. Woolas, 2010). The court upheld Mr Watkins petition for the first two claims: beyond reasonable doubt the statements relating to extremists and violence were false, they related to the personal conduct or character of Mr Watkins, and $\mathrm{Mr}$ Woolas had no reasonable grounds for believing the statements were true and did not believe they were true ( $R$ (Woolas v Parliamentary Election Court, 2010). As a result, the Court declared the election of Mr Woolas void and he lost his seat in Parliament. The third claim that $\mathrm{Mr}$ Watkins reneged on his promise to live in the constituency was deemed to be a false statement, but not one that was an illegal practice in contravention of S106
RPA as it was a political matter, rather than one that spoke to Mr Watkins' personal character or conduct.

During the general election campaign in 2015, a memo was leaked that falsely indicated that the Scottish Nationalist Party leader Nicola Sturgeon wanted the Conservative Party leader David Cameron to be re-elected as Prime Minister. Alistair Carmichael of the Liberal Democrat Party originally denied that he knew anything about the memo, but following a cabinet inquiry, he was forced to acknowledge that he had been aware that the memo was going to be leaked. In effect, he admitted to having lied during the election campaign. The court agreed that Mr Carmichael had lied (Timothy Morrison and Others v. Alistair Carmichael MP, 2015, p. 44-45) but he did not lose the election petition and did not lose his seat as an MP. The court stated:

We are not persuaded that the false statement proved to have been made was in relation to anything other than the first respondent's awareness (or lack of awareness) of a political machination. Accordingly we are not satisfied beyond reasonable doubt that the words used by the first respondent amounted to a "false statement of fact in relation to [his] personal character or conduct. (Timothy Morrison and Others v. Alistair Carmichael MP, 2015, p. 59)

Carmichael lied but could not be held to account because the lie fell outside S106 RPA. According to UK law, false statements that relate to political matters are not impermissible during campaigns.

These two cases indicate that existing UK electoral law, although a useful starting point for discussion of how to develop laws that might help regulate deliberation, is framed in such a way and has such limited scope in the UK that it can have almost no impact on referendum campaigns. An election for a place in Parliament is a contest between a limited number of individuals that each represent a wide-range of policy positions. The character and conduct of those individuals is therefore an important factor in a person's voting decision. In a referendum, on the other hand, particularly a national one, the opposite is true: there are usually a wide-ranging number of people campaigning to support a specific policy position. This greatly reduces the value of attacking individuals involved in a referendum campaign, and in the UK's recent EU membership plebiscite false statements tended to be about political positions, such as migration and public budget issues, rather than personal character or conduct. Therefore, if legislation is to give the courts the authority to declare the making of false statements an illegal practice during referendum campaigns, it needs to be extended to include political statements, and not be restricted to statements relating to "personal character or conduct". This extension could also be applied to campaigns for the election of representatives. This distinction between political statements and statements relating to personal character or conduct is not easy to 
draw Hoar (2011), but it would be useful, as Grist (2015) suggests: "to assess whether this offence [of making a false statement], and all other relevant offences, properly cover conduct that a modern electorate considers should invalidate elections". For example, does the electorate think Alistair Carmichael should have been censured for lying, and Woolas also censured for making a false statement about his rival's pledge to live in the constituency they were contesting? Although UK law is the focus for analysis in this article, there is also scope for comparative research that includes the law relating to false statements in other parts of the world such as the US and Australian states.

Freedom of speech during political campaigns is an important principle and any law regulating statements made during the course of a political campaign needs to make sure it does not excessively restrict freedom of speech and political debate (Rowbottom, 2012). It is expected that false statements remain as only being regulated in specific contexts, Alexander and Sherwin (2003) but if the scope for challenging statements is extended, then freedom of speech must be considered. As Suiter and Reidy (2015) put it: "In general, the requirement to regulate referendums is framed in terms of normative assumptions and in particular in terms of regulated equality versus maximum democratic freedoms". Space precludes a full analysis, in relation to freedom of speech, of the advantages and disadvantages of different approaches to framing the law relating to false statements and how it might be implemented in practice. The presumption here is simply that the more regulation is imposed on political campaigning and activity, the greater there is a chance of restricting freedom of speech beyond what is necessary, and that this issue should be carefully considered before electoral law is reformed.

\section{False Statements in the UK Plebiscite and Increasing the Scope of Electoral Law}

The discussion of the scope of false statements continues by looking at two examples of misleading claims from the UK plebiscite on EU membership: the " $£ 350$ million a week" and "invasion of Turkish migrants" claims. As both these claims are political matters and do not relate to personal character or conduct, there is currently no recourse in law either to sanction the use of the information as presented, or to hold to account those that used this information to influence the referendum result. Assuming that there is a need to increase the accuracy and integrity of statements in political campaigning, the question addressed in this section is how electoral law might define when a misleading political statement is an illegal practice. Misleading statements are a concern because they manipulate public debate and have the potential to unfairly influence people's voting decisions. Political campaigning, though, tends to be robust and the line between accuracy and inaccuracy may often be blurred as campaigners vie for the best way to present their politi- cal position. This means that, if the threshold is set too low, there could be a high number of statements open to challenge and the freedom of political campaigning could be excessively restricted. Furthermore, the courts do not want to be dragged excessively in to arguments of a political nature (Watkins v. Woolas, 2010, p. 118). On the other hand, if the threshold for a false statement is set too high, the law will not act as a deterrent to the use of misleading or inaccurate statements. Next, the article considers some factors that might be taken in to consideration when deciding whether a misleading statement is an illegal practice: the extent of the impact on the result, the regularity of its use, whether it needs to be both misleading and inaccurate, and deliberately or just negligently used.

The misleading claim that the UK's EU membership costs $£ 350$ million pounds a week is based on a theoretical gross figure of the UK's financial contribution. Importantly, though, this figure of $£ 350$ million does not include the abatement negotiated in the 1980s, which reduced the money sent to the EU in 2016 to $\mathrm{f} 267$ million per week, and ignores the funds the UK receives from the EU through, for example, regional development funds, which further reduced the net contribution to $£ 181 \mathrm{mil}-$ lion per week in 2016. Office of National Statistics Report (2017) It is false, therefore, to claim that EU membership costs the UK $£ 350$ million per week and that this amount could be spent on other public services in the UK, if the UK left the EU. It is a clear example of a misleading and inaccurate statement that distorts the quality of the public debate and limits effective deliberation between citizens, but should it be an illegal practice according to electoral law? This claim was a high-profile part of the Leave campaign and was transported around the country on the side of a bus. It was the most remembered slogan from the campaign and a significant percentage of people believed the claim, despite the regular, informal challenges to its veracity (Ipsos MORI, 2016). Although causality between any specific campaign slogan and voting decisions is difficult to prove, the " $£ 350$ million a week" claim is likely therefore to have significantly manipulated voting decisions. This claim was also an objectively verifiable claim about current, ongoing practice, not a prediction whose accuracy or likelihood could be disputed. Finally, the "£350 million a week" claim was used deliberately throughout the campaign. It was not a mistakenly attributed figure and there was no defence possible that those making the claim were unaware it was misleading or inaccurate. Therefore, even if the law set a relatively high threshold that required false statements to be repeated, objectively verifiable claims that were likely to have a clear impact on people's voting preferences, and also to be misleading, inaccurate, and deliberately, knowingly made, the " $£ 350$ million a week" claim is likely to be deemed a false statement and an illegal practice. Our second example is not as clear-cut.

The second misleading statement analysed here is the claim that a wave of Turkish migrants would come to 
the UK, if it stayed in the EU: "we can expect to see an additional million people added to the UK population from Turkey alone within eight years" (Boffey \& Helm, 2016). This scaremongering on its own is difficult to regulate in law because it is just the expression of an opinion linked to a possible, if unlikely, political event, and therefore unlikely to be in scope of a law relating to false statements. This is a regular part of political campaigning and in general it is up to the voter to decide whether they value this type of persuasion. However, the misleading presentation of the political and legal reality underpinning this statement might justify the wider "invasion of Turkish migrants" claim being considered a false statement according to electoral law.

A government minister and member of the Vote Leave campaign group, Penny Mordaunt, stated in a BBC interview on 22nd May 2016 that Turkish EU membership was imminent and that the UK could not stop this, even if it was an EU member, as it did not have a veto over accession decisions (BBC News, 2016). This is misleading for two reasons. First, from a legal perspective the UK, as an EU Member State, could veto the accession of Turkey to the EU, if it was proposed, because unanimous approval is needed from the Council of the EU. Penny Mordaunt, therefore, made a misleading and factually inaccurate statement based on a misunderstanding of the law to support the claim about migration. However, if we consider the other criteria suggested above, it seems unlikely that this specific comment would come within the definition of a false statement. The inaccurate claim about the UK's veto is unlikely to have had a significant impact on voting, as it was a negligent, one-off mistake in an interview rather than a deliberately repeated campaign slogan. Despite being inaccurate and misleading, this sort of mistake, as long as it does not start to be repeated, seems difficult to justify as falling within the scope of legislation that defines false statements, and is perhaps best dealt with in the interview itself.

Secondly, from the political perspective, although accession talks are formally alive, the likelihood of Turkish membership of the EU had receded considerably in the years prior to the UK's vote on EU membership. For example, Chancellor Angela Merkel stated on 16th March 2016 that Turkey's bid to join the EU was "really not on the agenda now" (Lorenz, 2016). Turkish EU membership was not likely, therefore, to imminently trigger a wave of migration of new EU citizens, if the UK did not leave the EU. Is this sort of misrepresentation of the current political reality sufficient to fall within the scope of false statements, according to electoral law? It could be argued that this is such a clear misreading of a current political position that it should be treated as misleading and inaccurate. The " $£ 350$ million a week" claim, though, is a misleading and inaccurate presentation of a verifiable fact, whereas the claim that Turkish accession to the EU is imminent is based on a misleading interpretation of the current political situation regarding the status of Turkey's application to be an EU member, which could change. The wider claim of an invasion of Turkish migrants has unsound foundations and is misleading in the sense that it is very unlikely to occur. However, it is still a prediction that could occur, if Turkey was granted EU membership, and the UK chose not to use their veto; however unlikely this may be. Therefore, despite its potential impact on voting and its repeated use, this wider "invasion of Turkish migrants" claim is not a verifiable fact that would be likely to fall within the scope of the definition of a false statement even if it was extended to include statements of a political character. If this sort of statement were deemed false, then it would significantly extend the scope of electoral law and substantially lower the threshold at which a statement becomes an illegal practice. This would require the regulators and courts to regularly assess political matters and could significantly limit free speech during political campaigns.

The decision rests with the drafters of any future legislation whether they want to limit the definition of false statements only to claims, like the $\mathbf{f 3 5 0}$ million pounds a week claim, that are verifiable facts, have a significant impact on voting, and are deliberately repeated despite being inaccurate and misleading. Or whether, perhaps, they follow the Advertising Standards Agency's wider approach to defining misleading statements. Advertisements are misleading if they are likely to deceive consumers and are likely to cause consumers to take transactional decisions that they would not otherwise take, even when they do not include false information (UK Government, 2008). This approach would mean the second Turkish migrant claim is likely to be misleading enough to bring it within scope of a law relating to false statements. The claims discussed show that there is a need to extend the definition of a false statement as it stands in UK electoral law to include political statements, not just statements made about a political rival's personal character or conduct. Deciding how to define a false statement in law, though, requires further analysis and there are a number of difficult issues that need addressing. For example, where does the burden of proof lie? Should there be an obligation of truthfulness written in to the law that would require the person making the statement to demonstrate beyond reasonable doubt that the statement is not false, as is found in some Australian states? Does the respondent need to have knowingly made a false statement? Does manipulation of voting intentions need to be proved beyond doubt? These questions and others will need to be addressed when deciding how to widen the definition of a false statement in political campaigns beyond personal conduct and character.

\section{How Should a New Law Be Regulated and Enforced?}

In the UK there is no formal process to challenge false statements during campaigning, or an organisation with overall responsibility for identifying when statements are inaccurate and/or misleading. The electoral law on false statements is applied retrospectively in the election 
court after the election has taken place. The UK Statistics Authority (UKSA), though, has been involved in verifying the accuracy of campaign claims through its statutory objective of promoting and safeguarding the production and publication of official statistics that "serve the public good". As a result, during the campaigning, Norman Lamb MP asked the UKSA to assess the " $£ 350$ million a week" claim against this standard. Sir Andrew Dilnott, Chair of the UKSA, replied that the claim that leaving the EU would free up $£ 350$ million to spend in the UK on other priorities, such as the NHS, was potentially misleading (UKSA, 2016). The Vote Leave campaign responded twice to Andrew Dilnott's letters to challenge the UKSA explanation of the available statistics; insisting that $f 350$ million a week would be available to spend elsewhere in the public sector, if the UK left the EU (UKSA, 2016). This misleading claim has continued to be used since the plebiscite result despite the UKSA intervention, which is advisory and not legally enforceable. The current chairman of the UKSA wrote to Boris Johnson in September 2017 to rebuke him for continuing to use this figure and remind him that "It is a clear misuse of official statistics" (UKSA, 2017). This UKSA experience highlights the political nature of the role of evaluating the accuracy of statistics used in campaigns, and also the need for an authority that can robustly examine the use of statistics and enforce their decisions.

So, how can the law relating to false statements during political campaigns be enforced and how can people that use misleading statements be held to account? There are likely to be two phases to the legal evaluation of potentially false statements. First, a formal, nonjudicial opportunity for citizens to query whether a statement is accurate and/or misleading. This is not limited to statements about personal character or conduct, but it may perhaps be prudent to limit the non-personal scope to statements based on statistics or a legal position that can be objectively assessed. To have an effect on deliberation and the quality of public discourse the assessment of the accuracy of campaign statements will need to be done in a timely manner to stop the spread of misinformation, and so that a retraction or correction can be ordered, where appropriate. A formal, non-judicial process should enable swifter, in-campaign resolution of issues of misinformation or misleading statements, which is preferable to post-event accountability that has no impact on the campaign already run. This should also reduce the burden on the courts, which will be reserved for appeals and more complex cases. The principle role at this first stage would therefore be to adjudicate whether a statement made during the campaign was false, and perhaps to order corrective action.

A key decision is selecting the independent body that would adjudicate on whether statements are false. A number of public bodies could take on this role, such as the Electoral Commission, which is the UK electoral regulator, or the Advertising Standards Agency. The Electoral Commission, despite already overseeing and adjudi- cating on financial and administrative aspects of referendums, have repeatedly stated that they think it inappropriate for their role to be extended in to more political territory that could put their independence at risk (The Electoral Commission, 2016, p. 7). The Electoral Commission (2016) states:

The role of regulating the truthfulness of campaign arguments would draw us into political debate and compromise the perception of our independence and neutrality that is required for our current roles. This would not be in the best interests of voters or improve public confidence in the regulatory system. (p. 52)

The Advertising Standards Agency relinquished a role that included political campaign communications because of the risk of damage to the perception of its independence. This was after the political controversy that followed its decision to rule against an advert used by the Conservative party depicting the then Labour leader Tony Blair with "demon eyes" (McCann, 1997). The decisions of the body that investigates complaints about practices during political campaigning will be challenged, as we saw from Vote Leave's response to the UKSA's assessment of the " $£ 350$ million a week" claim. A new body, such as an Office of Electoral Integrity might need to be established. This was already proposed to the Houses of Parliament as an Early Day Motion in July 2016. Ironically, one of the proposers was the MP found guilty of lying, Alistair Carmichael. Alternatively, the politicisation of the process could be reduced by including citizens in the decision-making process. A citizens' jury made up of a random, representative sample of the population could be convened for the duration of the campaign period as part of the regulatory body charged with overseeing the veracity of campaign claims. Based on the established methodologies and good practice of mini-publics (Gronlund, Bachtiger, \& Setala, 2014), this citizens jury would hear from experts, deliberate and then recommend whether the statement(s) presented to them for consideration was misleading and inaccurate, and therefore a false statement according to the law. Whatever option is taken, the independence of the regulatory body will remain an important aspect of its legitimacy and will need to be managed and defended in the politically charged atmosphere of a political campaign.

Secondly, the decision-making process would need a court or tribunal to review the initial decision taken by the regulatory body as to whether a statement is false, and to hold further enforcement powers. The petition to the court, if the law on false statements were extended, would be for a statement to be voided, rather than the result of the vote. The sanction imposed in the Woolas case of voiding the result of the vote is unlikely to be proportionate for referendums. In a general election it is a single member of parliament that loses their seat and the rerun of the vote in a single constituency is not a large administrative task. Rerunning a national vote because 
of a false statement is likely to be disproportionate to the level of offence, unless perhaps where there were a large number of egregious offences used to manipulate voters that had a direct, significant and demonstrable impact on the result. As with current election law, the election court would likely be able to issue an injunction to stop statements being used further. They may also need legal powers to fine organisations that continue to use statements even after the regulator issues a negative decision. As the main sanctions for false statements will be fines and injunctions on the use of claims and campaign slogans, the sooner these decisions can be reached, the greater the influence on the quality of discourse during the campaigns. Requiring campaigns to publicly correct misleading statements, perhaps through leaflets or other media outlets, could be an effective response as it would have financial and reputational implications, and could be swiftly implemented.

There is also the question of personal liability. A fine would reduce the budget of the campaign group and their ability to campaign for their preferred outcome and will act as a deterrent to some degree. Personal liability, though, is a stronger incentive to stop the use of false statements during campaigns than an injunction or a fine, which the campaign group may think is worth the cost. Furthermore, by the time an injunction is issued, the false statement may have had the desired effect of manipulating public opinion, and the campaign group may be little inconvenienced by the injunction. The option of personal liability is therefore important if the law is to be a strong deterrent for false statements.

Holding an individual or individuals to account for false statements through electoral law is more difficult for a political campaign prior to a referendum, than it is for a campaign to elect a political representative. During the campaign for representative election, the candidate is easily identifiable as the political actor ultimately responsible for false statements, and their removal from office is a direct and proportionate response. During a referendum campaign to win a policy vote, a campaign group, rather than an individual, is responsible for decisions about its slogans and statements. Moreover, no individual will directly benefit politically from using false statements during a campaign about a policy issue. It would be possible to require the nomination of a lead campaigner from each of the official campaign groups nominated prior to a UK public vote, who would be responsible for any false statements made. Perhaps this could be appropriate for a high-profile decision such as putting the " $£ 350$ million a week" claim on the side of a bus, where authorisation from the campaign group to use a statement would almost certainly have been given. However, it is less clear when a "lead campaigner" might be held responsible for false statements made by campaigners or other politicians. If someone could be held personally accountable, the question then arises of what sanction to impose. Should a politician be removed from their political office for an offence of making false state- ments during a referendum campaign, and is a fine the only option for a member of a campaign group who is not a politician? The question of effective enforcement and personal liability for false statements during political campaigning is therefore a difficult one to resolve.

\section{Strengthening Citizen Deliberation}

Broadening electoral law relating to false statements and increasing regulatory control, which is the main focus of this article, will have an impact on deliberation during political campaigns, but, as the discussion above has highlighted, there are significant challenges in drafting legislation that will effectively define and reduce the proliferation of false statements. Even if these challenges are overcome, misleading statements will only be reduced to a limited degree, particularly given the need to uphold the commitment to free speech. Control of the campaign discourse will also largely remain with the main political actors. The legitimacy of election and referendum campaigns would also benefit, therefore, from complementing the legal restrictions on false statements with enhanced opportunities for citizen-focused deliberation, which should reduce the impact of misleading and inaccurate statements more generally. One way to achieve this is through the application of deliberative democratic instruments:

The theory and practice of deliberative democracy, in which great strides have recently been taken in finding new ways in which to engage the popular participation of citizens in democratic decision-making, offers a vehicle with which to introduce good practice in referendums. (Tierney, 2015)

Strengthening the deliberative environment in this way, for both elections and referendums, should facilitate reasoned debate between citizens, allow citizens' voices to be heard, and mean that they are better informed at the point of voting, which addresses one of the most common criticisms of referendums (Tierney, 2012). It should also help reduce the current dominance of personality and party politics (The Electoral Reform Society, 2016). Increasing reasoned deliberation should reduce the manipulative effect on voting of false campaign claims and slogans, and allow a more equal, effective and legitimate reflection of the popular will when voting for a political representative or policy (Kildea \& Smith, 2016).

Decision-making bodies and researchers across the world have been experimenting with a wide range of democratic innovations at all levels of governance for many years (Smith, 2009). With these innovations in deliberative democracy well tested now and with key principles becoming established (Fung, 2007; Gronlund, Bachtiger, \& Setala, 2014), it is time to move from experimentation to implementation of deliberative democracy in to political systems (Council of Europe, 2018; The Constitution Unit, 2018; The Electoral Reform Society, 
2016). Events based on mini-public methodologies, such as citizens assemblies and citizen juries, are perhaps the most suitable to have the positive influence on political campaigning outlined above. Often these have been stand-alone democratic instruments (Citizens Assembly for Northern Ireland, 2018; Organ, 2018; Renwick et al., 2017), but they have also been combined with direct democratic processes. Perhaps the best-known example is the Irish citizens' assembly that was part of the process of setting the terms for a referendum on abortion (Ireland Citizens' Assembly, 2017). Much of the evidence from Ireland suggests that citizens' assemblies can have a positive effect on wider public discourse during referendum campaigns (The Constitution Unit, 2018, p. 100). There are, therefore, a range of deliberative mechanisms with a tested methodology that could be implemented to enhance deliberation in political campaigning, prior to both referendum and election votes.

Although these deliberative instruments have been tested and analysed, and could be implemented, the permanent institutionalisation of mini-publics in democratic processes is still in its infancy. Europe's first institutionalized deliberative body with annual rotation of randomly selected participants will be established in Madrid this year. There are still a number of issues related to deliberative democracy, and mini-publics in particular, that need further examination (Elstub \& McLaverty, 2014). It is unclear exactly how deliberative democratic instruments will fit in to existing governance structures. At what stage of the referendum process should the citizens' assembly be held? How would these events interact with other sites of deliberation? What should the outcome of these events be? More specifically, should the recommendations from a citizens' assembly impose obligations, or just be advisory? (Setala, 2006) This would have to be considered in light of the significant cost of these events, and the amount of time participants will have committed. As would the need to ensure that a citizens' assembly has impact beyond the relatively limited number of people that physically participate. Again, there would need to be a regulatory body responsible for these deliberative events to oversee their design and operation and ensure, for example, that interest groups do not capture their agenda and outcomes. These and other important questions deserve extensive analysis once there is further formal, institutionalisation of these instruments as part of the deliberative process during election and referendum campaigns. Legal accountability for false statements will go some way to enhancing the deliberation of political actors, but it is also important to develop the voice of citizens, particularly given the challenges to drafting legislation that were discussed earlier in the article. Citizens' assemblies, or similar deliberative instruments, have the potential to make a significant contribution to the quality of deliberation during political campaigns, but they too face challenges, as these questions reflect, and will need to be carefully monitored. The next step is for the political establishment to accept the value of the deliberative role of citizens, and to have the political will to institutionalise these democratic instruments and work through any new challenges that arise during their introduction.

\section{Conclusion}

It is argued here that the scope of electoral law should be widened to include the ability to challenge false statements on political issues, and deliberative democracy should be institutionalised to give citizens formal, proactive opportunities for deliberation during political campaigns. There would be an improvement in the quality of the deliberative environment through a reduction in the use of false statements that unfairly manipulate citizens' voting preferences, and through citizens that are better placed to filter and interpret statements that are not misleading enough to fall within the definition of a false, illegal statement. Reducing political manipulation and strengthening the quality of citizen deliberation are important for both representative and direct democratic processes and their development should reflect common underlying principles for the democratic systems as a whole. "Voice" is equally as important in political campaigns for elected representatives as it is for referendums. All votes in legitimate democratic systems rely on wellinformed voters who have participated in a fair political campaign. The changes discussed in this article should increase the democratic legitimacy of the specific campaigns and the democratic system more broadly, and therefore increase trust in the democratic process and politicians, whose activities citizens can more effectively influence and hold to account. In turn, this should lead to a greater number of "happy losers" in elections and referendums, which will help reduce the type of divisiveness the UK has seen following its EU membership plebiscite, and help facilitate the implementation of referendum results. The changes proposed here are not a magic bullet that will resolve all the democratic ills that have been highlighted by the UK's recent use of direct democracy, and the discussion is part of a much wider debate. Further issues such as the provision of information, the role of the media, freedom of speech, the role of Parliament, and others, would benefit from further, perhaps comparative, research. Nevertheless, addressing the issue of false statements is an important, specific step in the wider efforts to improve the quality of deliberation in political campaigns and therefore a state's democratic legitimacy.

\section{Acknowledgments}

I would like to thank the anonymous reviewers and Prof. Mike Gordon for their time, and the comments that have helped develop this article.

\section{Conflict of Interests}

The author declares no conflict of interests. 


\section{References}

Alexander, L., \& Sherwin, E. (2003). Deception in morality and law. Law and Philosophy, 22(5), 393-450.

BBC News. (2016). EU referendum: Row over Turkey's membership bid escalates. BBC News. Retrieved from https://www.bbc.co.uk/news/uk-politics-eureferendum-36353013

Boffey, D., \& Helm, T. (2016). Vote Leave embroiled in race row over Turkey security threat claims. The Guardian. Retrieved from https://www.theguardian. com/politics/2016/may/21/vote-leave-prejudiceturkey-eu-security-threat?CMP=aff_1432\&awc= 5795_1541027299_d5664c4b391160e1ab3566a 20984fd32

Citizens Assembly for Northern Ireland. (2018). Citizens Assembly for Northern Ireland. Retrieved from https://citizensassemblyni.org

Council of Europe. (2018). Updating guidelines to ensure fair referendums in Council of Europe member States (Report). Brussels: Council of Europe. Retrieved from http://website-pace.net/documents/18848/ 4457779/20181211-Fpdoc19-EN.pdf/5149f5066792-48a5-8a5f-8e746dece17f

Dahl, R. (1989). Democracy and its critics. New Haven, CT: Yale University Press.

Elstub, S., \& McLaverty, P. (Eds). (2014). Deliberative democracy: Issues and cases. Edinburgh: Edinburgh University Press.

Full Fact. (2016). The $£ 4,300$ question: Would leaving the EU really make every household worse off? Full Fact: The UK's Independent Fact Checking Charity. Retrieved from https://fullfact.org/europe/4300question-would-leaving-eu-really-make-everyhousehold-worse

Fung, A. (2007). Minipublics: Deliberative designs and their consequences. In S. Rosenberg (Ed.), Deliberation, participation and democracy: Can the people govern? (pp. 159-183). London: Palgrave Macmillan.

Grist, R. (2015). Challenging elections in the courts. Public Law, July, 375-385.

Gronlund, K., Bachtiger, A., \& Setala, M. (2014). Deliberative mini-publics: Involving citizens in the democratic process. Colchester: ECPR Press.

Henderson, A., \& Tierney, S. (2018). Can referendums foster citizen deliberation? The experience of Canada and the United Kingdom. In M. Keating \& G. Laforest (Eds.) Constitutional politics and the territorial question in Canada and the United Kingdom (pp. 159-177). London: Palgrave Macmillan.

Her Majesty's Treasury. (2016). HM Treasury Analysis: The long-term economic impact of EU membership and the alternatives. London: Her Majesty's Treasury. Retrieved from https://assets.publishing.service. gov.uk/government/uploads/system/uploads/ attachment_data/file/517415/treasury_analysis_ economic_impact_of_eu_membership_web.pdf

Hoar, F. (2011). Public or personal character in election campaigns: A review of the implications of the judgment in Watkins v. Woolas. The Modern Law Review, 74(4), 607-616.

Ipsos MORI. (2016). Immigration is not the top issue for voters in the EU referendum. Ipsos MORI. Retrieved from https://www.ipsos.com/ipsos-mori/en-uk/ immigration-now-top-issue-voters-eu-referendum

Ireland Citizens' Assembly. (2017). Final report on the Eighth Amendment of the Constitution. Dublin: Ireland Citizens' Assembly. Retrieved from https://www.citizensassembly.ie/en/The-EighthAmendment-of-the-Constitution/Final-Reporton-the-Eighth-Amendment-of-the-Constitution/ Final-Report-on-the-Eighth-Amendment-of-theConstitution.html

Kildea, P., \& Smith, R. (2016). The challenge of informed voting at constitutional referendums. University of New South Wales Law Journal, 39(1), 368-400.

Lamond, I., \& Reid, C. (2017). The 2015 UK general election and the 2016 EU referendum: Towards a democracy of the spectacle. London: Palgrave Macmillan.

LeDuc, L. (2015). Referendums and deliberative democracy. Electoral Studies, 38, 139-148.

Lorenz, A. (2016). Merkel: Turkish EU-membership 'not on the agenda'. Euractiv. Retrieved from https:// www.euractiv.com/section/justice-home-affairs/ news/merkel-turkish-eu-membership-not-on-theagenda

McCann, P. (1997). Ad watchdog washes its hands of demon eyes. The Independent. Retrieved from www.independent.co.uk/news/ad-watchdogwashes-its-hands-of-demon-eyes-1236983.html

Mendelsohn, M., \& Parkin, A. (Eds). (2001). Referendum democracy: Citizens, elites and deliberation in referendum campaigns. London: Macmillan.

Mendez, F., Mendez, M., \& Triga, V. (2014). Referendums and the European Union: A comparative inquiry. Cambridge: Cambridge University Press.

Office of National Statistics. (2017). The UK contribution to the EU budget. Office of National Statistics. Retrieved from https://www.ons.gov.uk/economy/ governmentpublicsectorandtaxes/publicsector finance/articles/theukcontributiontotheeubudget/ 2017-10-31

Organ, J. (2018). Citizens Assembly for Europe interim project report. Retrieved from https://www. citizensassemblies.eu/en/resource

Parliament of the United Kingdom. (1983). Representation of the People Act 1983. London: Parliament of the United Kingdom.

Qvortrup, M. (Ed.). (2018). Referendums around the world. London: Palgrave Macmillan.

$R$ (Woolas) v The Parliamentary Election Court 2010 EWHC 3169 (Admin)

Renwick, A., Allan, S., Jennings, W., Mckee, R., Russell, R., \& Smith, G. (2017). The report of the Citizens Assembly on Brexit. Retrieved from http:// citizensassembly.co.uk/wp-content/uploads/2017/ 
12/Citizens-Assembly-on-Brexit-Report.pdf

Rowbottom, J. (2012). Lies, Manipulation and ElectionsControlling False Campaign Statements. Oxford Journal of Legal Studies, 32(3), 507-535.

Setala, M. (2006). On the problems of responsibility and accountability in referenda. European Journal of Political Research, 45(4), 699-721.

Smith, G. (2009). Democratic innovations-Designing institutions for citizen participation. Cambridge: Cambridge University Press.

Stone, J. (2017). Brexit lies: The demonstrably false claims of the EU referendum campaign. The Independent. Retrieved from https://www.independent.co. uk/infact/brexit-second-referendum-false-claimseu-referendum-campaign-lies-fake-newsa8113381.html

Suiter, J., \& Reidy, T. (2015). Do rules matter? Categorizing the regulation of referendum campaigns. Electoral Studies, 38, 159-169.

Tierney, S. (2012). Constitutional referendums: The theory and practice of republican deliberation. Oxford: Oxford University Press.

Tierney, S. (2013). Using electoral law to construct a deliberative referendum: Moving beyond the democratic paradox (University of Edinburgh School of Law Research Paper No. 2013/14). Edinburgh: University of Edinburgh, School of Law.

Tierney, S. (2015). Direct democracy in the United Kingdom: Reflections from the Scottish independence referendum. Public Law, 2015(4), 633-651.

Timothy Morrison and Others v. Alistair Carmichael MP, 2015 EC 90.

The Constitution Unit. (2018). Report of the Independent Commission on referendums. London: The Constitu- tion Unit, UCL. Retrieved from https://www.ucl.ac. uk/constitution-unit/sites/constitution-unit/files/ ICR_Final_Report.pdf

The Electoral Commission. (2016). Report on the 23 June 2016 referendum on the UK's membership of the European Union. London: The Electoral Commission. Retrieved from https://www.electoral commission.org.uk/_data/assets/pdf_file/0008/ 215279/2016-EU-referendum-report.pdf

The Electoral Reform Society. (2016). It's good to talk: Doing referendums differently after the EU vote. London: The Electoral Reform Society. Retrieved from https://www.electoral-reform.org.uk/latestnews-and-research/publications/its-good-to-talk

UK Government. (2008). Consumer protection from unfair trading regulations, 2008. London: UK Government.

United Kingdom Statistics Authority. (2016). Statement on contributions to the EU. United Kingdom Statistics Authority. Retrieved from https:// www.statisticsauthority.gov.uk/news/uk-statisticsauthority-statement-on-the-use-of-officialstatistics-on-contributions-to-the-european-union

United Kingdom Statistics Authority. (2017). Letter to Boris Johnson MP. United Kingdom Statistics Authority. Retrieved from https://www.statisticsauthority. gov.uk/wp-content/uploads/2017/09/Letter-fromSir-David-Norgrove-to-Foreign-Secretary.pdf

Vote Leave. (2016). Why Vote Leave. Vote Leave. Retrieved from http://www.voteleavetakecontrol.org/ why_vote_leave.html

Watkins $v$. Woolas (In the matter of the Representation of the People Act 1983) 2010 EWHC 2702 (QB).

\section{About the Author}

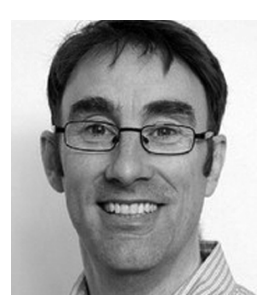

James Organ is a Lecturer at the School of Law and Social Justice, University of Liverpool. He is an expert in the area of participatory and direct democracy. He has published on citizen participation and the European Citizens' Initiative, and has an upcoming edited collection titled Direct participation in a Citizen's Europe published by ECPR. James works extensively with civil society organisations and advises EU institutions on developing EU level citizens participation. He has recently completed an EACEA “Europe for Citizens" funded project on the future of EU democratic participation that held mini publics in four EU member states and online deliberation, and is part of a project holding a deliberative forum in Northern Ireland in May. 